Article

\title{
Evaluation of Portable Rhodamine B Analyzer for Monitoring OH Radical Scavenging Demand in Ultraviolet Advanced Oxidation Processes
}

\author{
Sook-Hyun Nam $^{1}$, Ju-Won Lee ${ }^{1,2}$, Eun-Ju Kim ${ }^{1}$, Jae-Wuk Koo ${ }^{1}$ and Tae-Mun Hwang ${ }^{1,2, *(D)}$ \\ 1 Korea Institute of Civil Engineering and Building Technology—Environment Research Institute, \\ Goyang-si 10223, Korea; fpnsh@kict.re.kr (S.-H.N.); leejw0410@kict.re.kr (J.-W.L.); kej@kict.re.kr (E.-J.K.); \\ koojaewuk@kict.re.kr (J.-W.K.) \\ 2 Construction Environment Engineering, Korea University of Science \& Technology, Daejeon 34113, Korea \\ * Correspondence: taemun@kict.re.kr; Tel.: +82-31-910-0741
}

\section{check for} updates

Citation: Nam, S.-H.; Lee, J.-W.; Kim, E.-J.; Koo, J.-W.; Hwang, T.-M. Evaluation of Portable Rhodamine B Analyzer for Monitoring OH Radical Scavenging Demand in Ultraviolet Advanced Oxidation Processes. Sustainability 2021, 13, 13279. https:/ / doi.org/10.3390/su132313279

Academic Editors: Rodrigo Munoz, João Flávio Da Silveira Petruci and Fábio Rodrigo Piovezani Rocha

Received: 26 October 2021

Accepted: 26 November 2021

Published: 30 November 2021

Publisher's Note: MDPI stays neutral with regard to jurisdictional claims in published maps and institutional affiliations.

Copyright: (c) 2021 by the authors. Licensee MDPI, Basel, Switzerland. This article is an open access article distributed under the terms and conditions of the Creative Commons Attribution (CC BY) license (https:/ / creativecommons.org/licenses/by/ $4.0 /)$.

\begin{abstract}
A portable $\mathrm{OH}$ radical scavenging demand analyzer that can be installed and operated on site was developed to measure water quality indicators that influence the generation of $\mathrm{OH}$ radicals from UV/hydrogen peroxide reactions to determine the UV dose and the hydrogen peroxide injection concentration. Rhodamine $\mathrm{B}(\mathrm{RhB})$ was used as an indicator for the continuous measurement of the $\mathrm{OH}$ radical scavenging demand of four samples with different water quality parameters using the rapid, easy, and real-time UV-Vis spectrophotometer method. The results demonstrated that the estimated rate constant for the RhB color decay rate resulting from direct UV photolysis was low enough to verify its suitability as a probe compound. The mean values of the $\mathrm{OH}$ radical scavenging demand for target water samples at different organic concentrations were 20,659 $\mathrm{s}^{-1}$ for plant $\mathrm{N}$, $42,346 \mathrm{~s}^{-1}$ for plant C, 32,232 $\mathrm{s}^{-1}$ for plant $\mathrm{Y}$, and $81,669 \mathrm{~s}^{-1}$ for plant B. Variations in the monitoring results for the target water treatment plants suggest that on-site $\mathrm{OH}$ radical scavenging demands should be considered to determine the UV dose and the hydrogen peroxide injection concentration for the UV advanced oxidation process.
\end{abstract}

Keywords: $\mathrm{OH}$ radical; scavenging demand; portable analyzer; Rhodamine probe

\section{Introduction}

The advanced oxidation process (AOP) is a promising and attractive water treatment technique that reduces organic chemicals to trace levels [1,2]. The AOP generates $\mathrm{OH}$ radicals, the transient species which play a key role in aqueous photochemistry [3].

$\mathrm{OH}$ radical, which has strong oxidizing potential and non-selectivity, is a major oxidation species in the AOP [4,5]. However, the non-selective property of $\mathrm{OH}$ radical could result in a significant radical water matrix demand, which negatively impacts the efficiency of AOPs. OH radicals must be analyzed quantitatively to predict the removal rate of the target compound in the AOP process.

The primary species known for $\mathrm{OH}$ radical scavenging in water are dissolved organic matter (DOM) and carbonate, bicarbonate, nitrite, bromide ions, and halide species [6-8]. A higher concentration of scavengers has a negative impact on the oxidation potential and decreases the exposure of $\mathrm{OH}$ radical that can react with the target organic contaminants. To model and predict the removal rate of target substances in the AOP process, $\mathrm{OH}$ radical must be quantitatively analyzed and the effective $\mathrm{OH}$ radical scavenging demand calculated because $\mathrm{OH}$ radical scavenging demand varies with the water source $[9,10]$.

Rosenfeldt and Linden [11] reported a measuring method for the $\mathrm{OH}$ radical scavenging demand using the $\mathrm{R}_{\mathrm{OH}, \mathrm{UV}}$ concept. $\mathrm{R}_{\mathrm{OH}, \mathrm{UV}}$ is defined as the $\mathrm{OH}$ radical exposure per UV dose.

Para-chlorobenzoic acid (pCBA) is widely used as a probe for measuring $\mathrm{OH}$ radical scavenging factors in AOP because of its high reactivity with $\mathrm{OH}$ radical and low reactivity 
with direct pyrolysis [11,12]. However, this method is difficult to continuously analyze because it uses high-pressure liquid chromatography (HPLC) to estimate the pCBA concentration. Other methods that use fluorescein or methylene blue as a probe have also been reported [10,13-15].

Kwon et al. [16] have proposed a spectrophotometric method based on the $\mathrm{R}_{\mathrm{OH}, \mathrm{UV}}$ concept that uses Rhodamine $\mathrm{B}(\mathrm{RhB})$ to measure the $\mathrm{OH}$ radical scavenging demand. This method has the advantage of involving relatively simpler and faster measurements than the $\mathrm{R}_{\mathrm{OH}, \mathrm{Uv}}$-pCBA method. The $\mathrm{R}_{\mathrm{OH}, \mathrm{Uv}}-\mathrm{RhB}$ method procures the $\mathrm{OH}$ radical scavenging demand by determining the second order rate constant for the $\mathrm{OH}$ radical reaction and quantitatively measuring $\mathrm{OH}$ radical using $\mathrm{RhB}$ as a probe. A method to measure $\mathrm{OH}$ radical scavenging demand using the $\mathrm{R}_{\mathrm{OH}, \mathrm{UV}}-\mathrm{RhB}$ method has been proposed in previous studies $[17,18]$.

The RhB evaluation method has been used to verify the accuracy and effectiveness of fast spectrophotometry in predicting the removal efficiency of a target compound using the $\mathrm{UV} / \mathrm{H}_{2} \mathrm{O}_{2}$ process [19]. The decay rate of the probe compound is used to determine the $\mathrm{OH}$ radical scavenging demand using various calculation methods and is expressed as follows [10]:

$$
\sum \mathrm{k}_{\mathrm{s}, \mathrm{OH}}[\mathrm{S}]_{\mathrm{i}}=\mathrm{k}_{\mathrm{H}_{2} \mathrm{O}_{2}, \mathrm{OH}} \times \frac{\mathrm{m}}{\mathrm{b}}-\mathrm{k}_{\mathrm{RhB}, \mathrm{OH}}[\mathrm{RhB}]
$$

where $\Sigma \mathrm{k}_{\mathrm{S}, \mathrm{OH}}[\mathrm{S}]_{\mathrm{i}}$ is the $\mathrm{OH}$ radical scavenging demand $\left(\mathrm{s}^{-1}\right) ; \mathrm{k}_{\mathrm{H} 2 \mathrm{O} 2, \mathrm{OH}}$ is the second order rate constant of $\mathrm{OH}$ radical and $\mathrm{H}_{2} \mathrm{O}_{2}\left(2.7 \times 10^{7} \mathrm{M}^{-1} \mathrm{~s}^{-1}\right) ; \mathrm{k}_{\mathrm{RhB}, \mathrm{OH}}$ is the second order rate constant $\left.\left(2.5 \times 10^{10} \mathrm{M}^{-1} \mathrm{~s}^{-1}\right)\right)$ of $\mathrm{OH}$ radical and $\mathrm{RhB}$; $[\mathrm{RhB}]$ is the initial concentration $(\mathrm{mol} / \mathrm{L}) ; \mathrm{m}$ is the slope of the graph between $1 / \mathrm{H}_{2} \mathrm{O}_{2}$ (x-axis) and $1 / \mathrm{R}_{\mathrm{OH}, \mathrm{UV}}$ (y-axis); and $\mathrm{b}$ is the $\mathrm{y}$-intercept of the graph.

This method measures the decay rate of RhB, using a bench-scale low-pressure collimated beam UV device (LP-UV CBD), when the $\mathrm{OH}$ radical in water is exposed to it. The $\mathrm{R}_{\mathrm{OH}, \mathrm{UV}}-\mathrm{RhB}$ spectrometric method used in previous studies is inconvenient because the RhB decay rate must be measured by collecting samples over time using a UV-Vis spectrophotometer in the laboratory. Another disadvantage is that a large sample volume of over $250 \mathrm{~mL}$ is required because samples used to measure the $\mathrm{RhB}$ decay rate must be discarded after measurement.

To address these issues, this study developed a real-time spectrophotometric portable $\mathrm{OH}$ radical scavenging demand analyzer that can detect the decay rate of $\mathrm{RhB}$ on field. The variability in the $\mathrm{OH}$ radical demand was compared with the results obtained from a long-term monitoring of the $\mathrm{OH}$ radical demand of different sand-filtered waters using newly designed equipment.

\section{Materials and Methods}

\subsection{Portable OH Radical Scavenging Demand Analyzer}

This study was carried out to develop a portable $\mathrm{OH}$ radical scavenging demand analyzer that detects the RhB decay rate as shown in Figure 1. In this equipment, the detector part of a typical collimated bead device equipped with low pressure ultraviolet (LP-UV CBD) used in a previous study was improved and a post-processing part was added to continuously measure the RhB decay rate and analyze the acquired data [16]. The size of this equipment was $50 \times 40 \times 56 \mathrm{~cm}(\mathrm{~L} \times \mathrm{W} \times \mathrm{H})$. The quartz reaction module was manufactured at a size of $7.5 \times 6 \times 5.5 \mathrm{~cm}(\mathrm{~L} \times \mathrm{W} \times \mathrm{H})$. A magnetic stirrer was attached to the bottom of the reaction module for mixing during the reaction. Two mercury lamps (TUV 4W/G4T5, Philips, Eindhoven, the Netherlands) were used as UV ray sources. The distance from the UV lamp to the light (path length, L), which influences accuracy, was $14 \mathrm{~cm}$. The UV dose $\left(\mathrm{mW} / \mathrm{cm}^{2}\right)$ was measured with a UV254 detector (UVX radiometer, UVP Co., Upland, CA, USA), and was found to be $0.5 \mathrm{~mW} / \mathrm{cm}^{2}$. Two fans and temperature sensors were installed to maintain the temperature at $25^{\circ} \mathrm{C}$. A sliding door was installed in the quartz cell reactor to facilitate the injection of samples and reagents. 


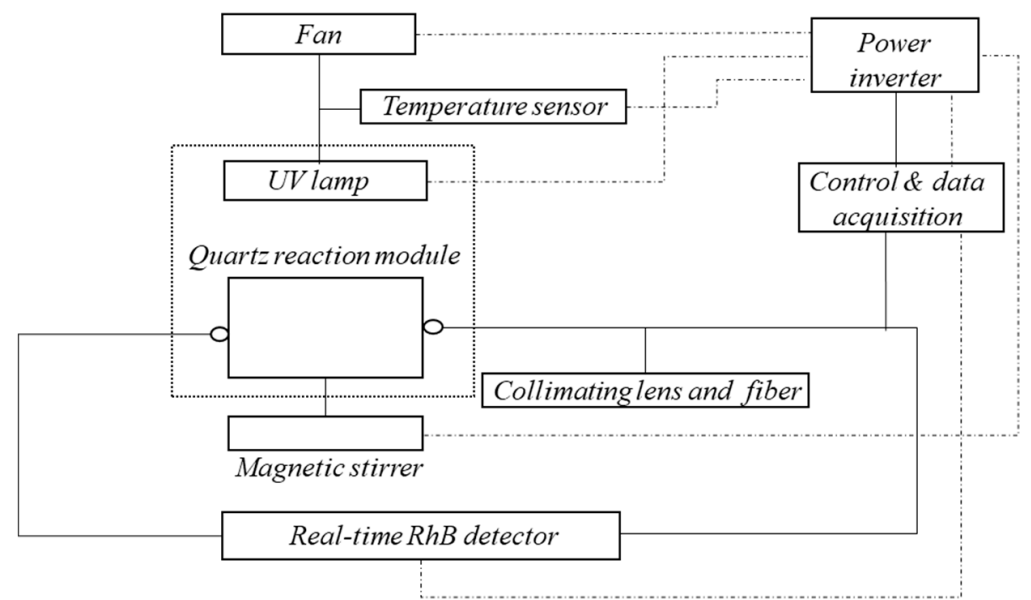

(a)

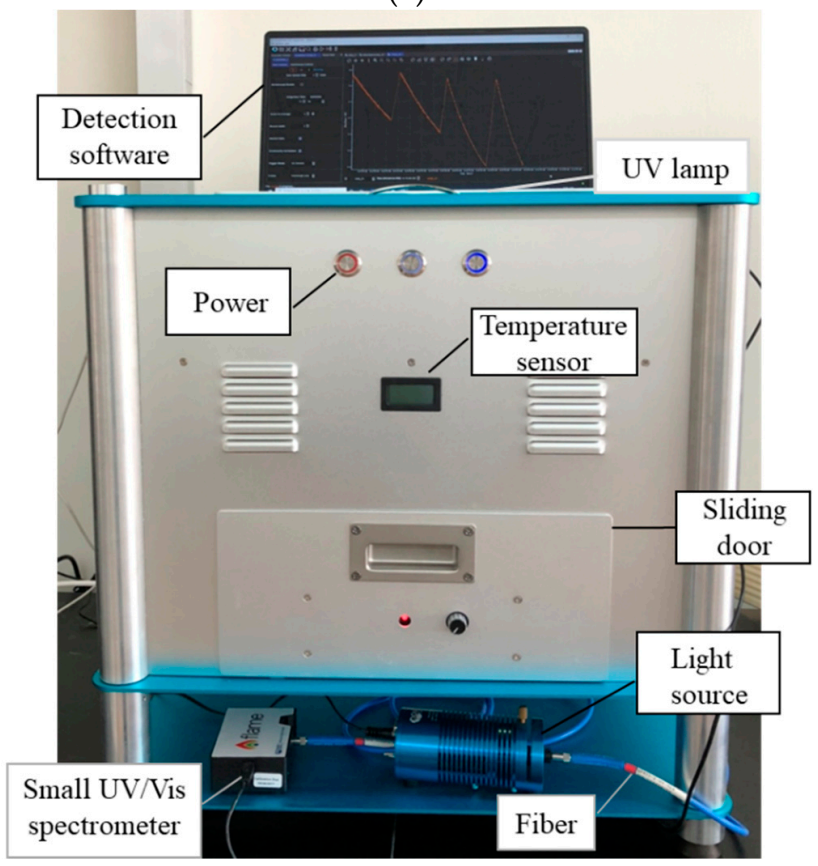

(b)

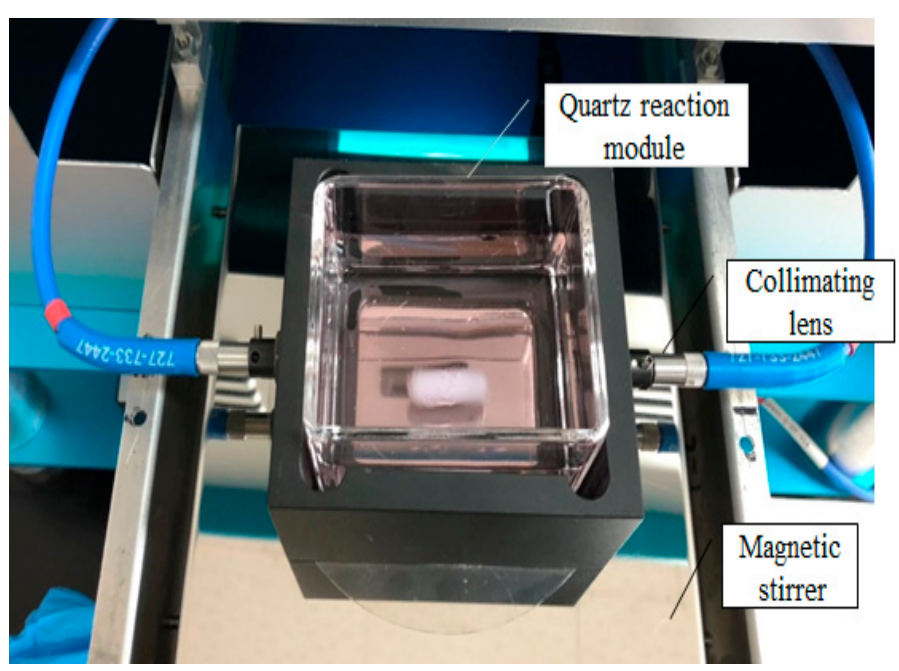

(c)

Figure 1. Development of a portable $\mathrm{OH}$ radical scavenging demand analyzer: (a) schematic diagram; (b) advanced collimated beam system; (c) quartz reaction module. 
A VIS-NIR Tungsten halogen light (360-2000 nm, Ocean Optics, Largo, FL, USA) was used as a light source for the detector in a small UV/Vis spectrophotometer (200-850 nm, Flame, Ocean Optics, Largo, FL, USA). The changing RhB concentration was measured by connecting the detector with a fiber (Single patch cord, Ocean Optics, Largo, FL, USA) and the fiber with a sensor. The data measured were analyzed using the OceanView spectroscopy software with a graphical user interface (Ocean Optics, Largo, FL, USA).

Photoreactions were induced by irradiating UV rays from the quartz reaction module. Outside the reaction module, the absorbance between reactions was measured continuously by a sensor unit connected to the Ocean Optics visible light source and a detector. RhB was injected into the sample with an initial concentration of $1 \mu \mathrm{M}$, and $\mathrm{H}_{2} \mathrm{O}_{2}$ was added at five different concentrations to collect data. The RhB absorbance was then measured and saved once every minute at the wavelength of $554 \mathrm{~nm}$. The RhB absorbance measured at $554 \mathrm{~nm}$ was converted to concentration by the RhB calibration curve and was used to calculate the RhB decay rate.

\subsection{Chemicals and Analysis Methods}

Every solution used in the experiment was prepared with $18 \mathrm{M} \Omega$ distilled water. RhB (95\%, Sigma-Aldrich, St. Louis, MO, USA) and hydrogen peroxide (30wt \% solution, Merck, Darmstadt, Germany) were also used. The hydrogen peroxide concentration was measured using test kits (Merck, Darmstadt, Germany). The dissolved organic carbon (DOC) of the target sample was measured using a total organic carbon (TOC) analyzer (TOC-VCPH, Shimadzu, Kyoto, Japan) and UV254 was measured with a UV/Vis spectrophotometer (DR 5000, HACH, Loveland, CO, USA). Alkalinity was titrated using Standard Method 2320B. Total dissolved solids (TDS) was measured using a conductivity meter (ORION 3 STAR, Thermo, Waltham, MA, USA).

\subsection{Test Water}

This study used filtered water from four different types of water treatment plants (N, C, Y, and B) in South Korea; the water quality parameters are listed in Table 1. The water quality parameters of the sand filtrate used at the four water treatment plants were different, with TOC and UV254 values showing the largest deviations. The TOC and UV254 of the filtrate at plants $C$ and $Y$ were both 1.5 times higher than those of plant $N$. The TOC and UV254 of the filtrate at plant B were 3.8 and 8.0 times higher than those of the filtrate at plant $\mathrm{N}$ and 2.5 and 5.3 higher than those of plants $\mathrm{C}$ and $\mathrm{Y}$, respectively. Furthermore, the filtrate at plant $C$ had the highest alkalinity and TDS values, which indicate the presence of inorganic species such as carbonates, bicarbonates, nitrites, and bromide ions that influence the $\bullet \mathrm{OH}$ scavenging demand [20].

Table 1. Water quality parameters of four water treatment plants in South Korea.

\begin{tabular}{ccccc}
\hline \multirow{2}{*}{ Parameter } & \multicolumn{4}{c}{ Water Treatment Plant } \\
\cline { 2 - 5 } & Plant C & Plant N & Plant Y & Plant B \\
\hline pH & $7.1 \pm 0.2$ & $7.2 \pm 0.3$ & $7.5 \pm 0.3$ & $6.9 \pm 0.3$ \\
\hline Turbidity (NTU) & $0.34 \pm 0.18$ & $0.23 \pm 0.18$ & $0.12 \pm 0.10$ & $0.31 \pm 0.25$ \\
\hline UV254 (abs./cm) & $0.038 \pm 0.008$ & $0.021 \pm 0.005$ & $0.032 \pm 0.002$ & $0.17 \pm 0.050$ \\
\hline DOC (mg/L) & $2.80 \pm 0.30$ & $1.84 \pm 0.60$ & $2.76 \pm 0.40$ & $6.96 \pm 0.80$ \\
\hline TDS (mg/L) & $150 \pm 7$ & $115 \pm 3$ & $135 \pm 3$ & $133 \pm 3$ \\
\hline $\begin{array}{c}\text { Alkalinity (mg/L } \\
\text { as CaCO })\end{array}$ & $45 \pm 7$ & $43 \pm 5$ & $40 \pm 2$ & $30 \pm 3$ \\
\hline
\end{tabular}

\subsection{Test Method}

RhB standard solutions were prepared at concentrations of $0,0.0625,0.125,0.25,0.5$, and $1 \mu \mathrm{M}$ and kept in a quartz cell reactor. Calibration curves were created at $554 \mathrm{~nm}$ using 
an RT RhB detector. RhB was injected at $1 \mu \mathrm{M}$, and $\mathrm{H}_{2} \mathrm{O}_{2}$ was injected at $0,0.29,0.44,0.88$, 1.03 , and $2.06 \mathrm{mM}$ into each sample from the four water treatment plants. The changes in $\mathrm{RhB}$ absorbance were monitored. The absorbance value at $554 \mathrm{~nm}$ of the real-time RhB detector was scanned 10 times, and the mean value was stored once every minute.

\section{Results}

\subsection{Analysis of RhB Standard Solutions}

In the quartz cell reactor, $\mathrm{RhB}$ standard solutions were injected at concentrations of 0 , $0.0625,0.125,0.25$. 0.5, and $1 \mu \mathrm{M}$. Figure 2 shows the calibration curves for these different concentrations. The standard deviation and the detection limit calculated from 5 replicate tests were 0.29 and 0.02 , respectively.

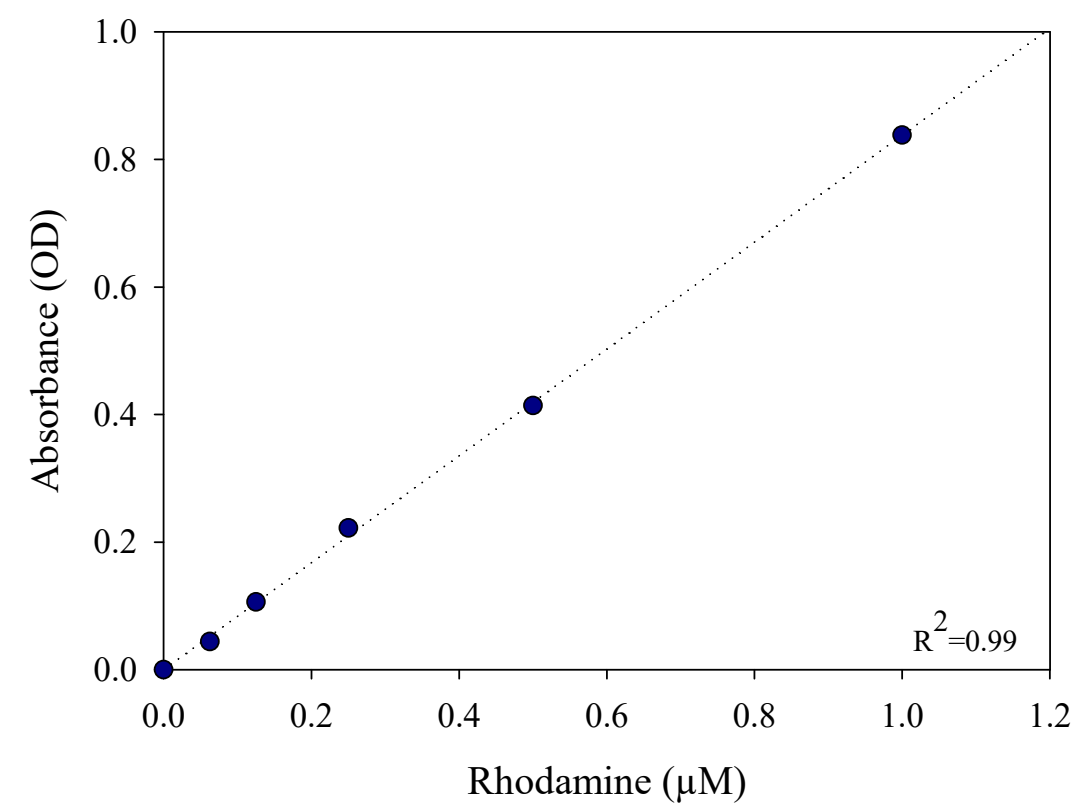

Figure 2. Calibration curve for RhB standard solutions at concentrations of $0,0.0625,0.125,0.25,0.5$, and $1 \mu \mathrm{M}$ for the portable $\mathrm{OH}$ radical scavenging demand analyzer.

\subsection{UV Photolysis Experiments for Target Samples}

When $100 \mathrm{~mL}$ of the sample was input to the quartz cell reactor of the developed portable $\mathrm{OH}$ radical scavenging demand analyzer, the depth was $3.5 \mathrm{~cm}$. Figure 3 shows the color decay rates for four different water treatment plant filtration samples when the UV dose was changed from 0 to $300 \mathrm{~mJ} / \mathrm{cm}^{2}$. RhB was injected at $1 \mathrm{uM}$, and $\mathrm{H}_{2} \mathrm{O}_{2}$ was changed from 0 to $2.06 \mathrm{mM}$. The first-order rate constants for the color decay rates of $\mathrm{RhB}$ in the direct UV photolysis condition, where $\mathrm{H}_{2} \mathrm{O}_{2}$ was not injected, were $0.000085 \mathrm{~cm}^{2} / \mathrm{mJ}$ (plant N), $0.000208 \mathrm{~cm}^{2} / \mathrm{mJ}$ (plant C), $0.000229 \mathrm{~cm}^{2} / \mathrm{mJ}$ (plant Y), and $0.000128 \mathrm{~cm}^{2} / \mathrm{mJ}$ (plant B) for first-order reactions. The estimated rate constant for the RhB color decay rate by direct UV photolysis was low enough to verify its suitability as a probe compound, which is consistent with the previous studies [16].

The results showed that the UV doses of the color decay rate of $\mathrm{RhB}$ in the four water treatment plant samples according to the $\mathrm{H}_{2} \mathrm{O}_{2}$ injection concentration were all different. In plants $\mathrm{N}, \mathrm{C}$, and $\mathrm{Y}$, changes were observed in the $\mathrm{RhB}$ color decay rate until the $\mathrm{UV}$ dose of $300 \mathrm{~mJ} / \mathrm{cm}^{2}$ for the $\mathrm{H}_{2} \mathrm{O}_{2}$ injections at $0.29,0.44$, and $0.88 \mathrm{mM}$. When $\mathrm{H}_{2} \mathrm{O}_{2}$ was injected at $1.03 \mathrm{mM}$ and $2.06 \mathrm{mM}$, the variations in the RhB color decay rate until the UV dose of $300 \mathrm{~mJ} / \mathrm{cm}^{2}$ were observed not to affect the slope of the curve. 


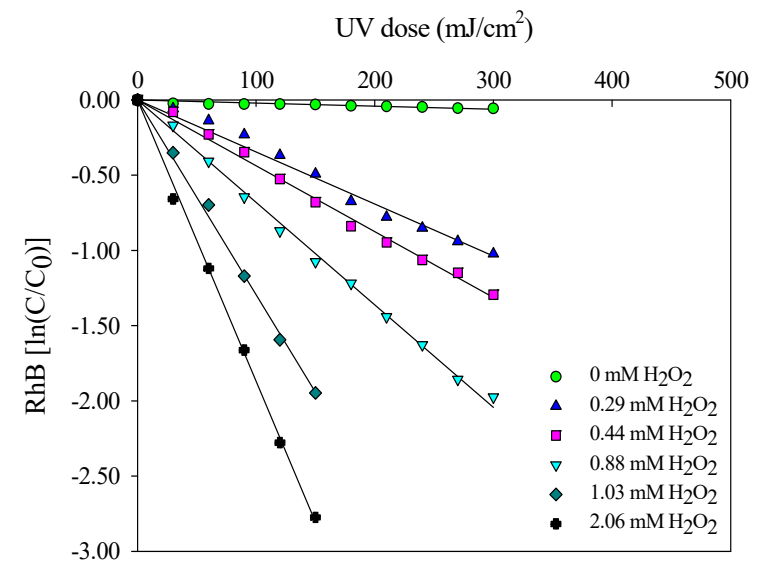

(a)

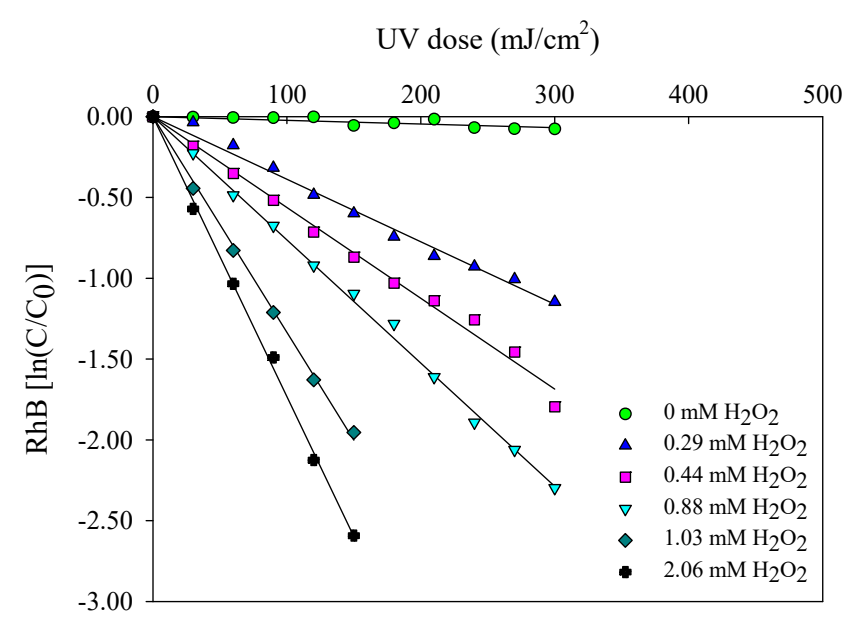

(c)

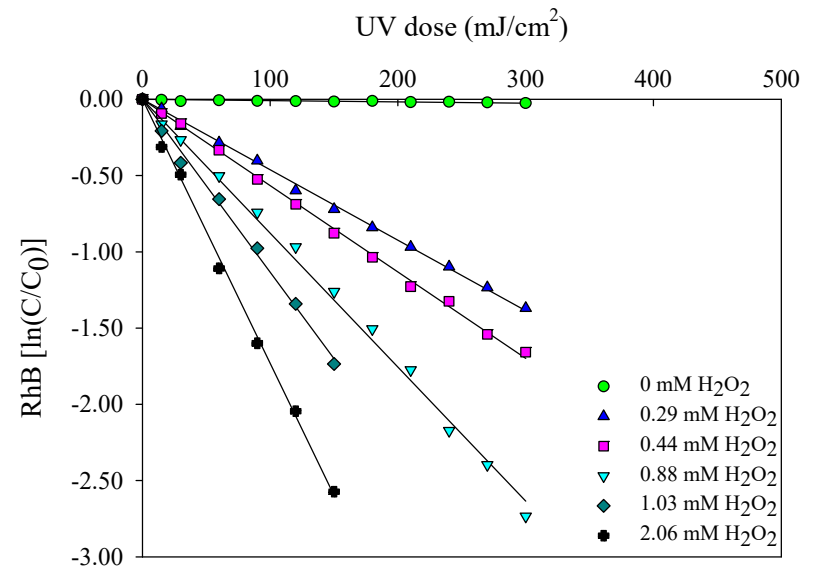

(b)

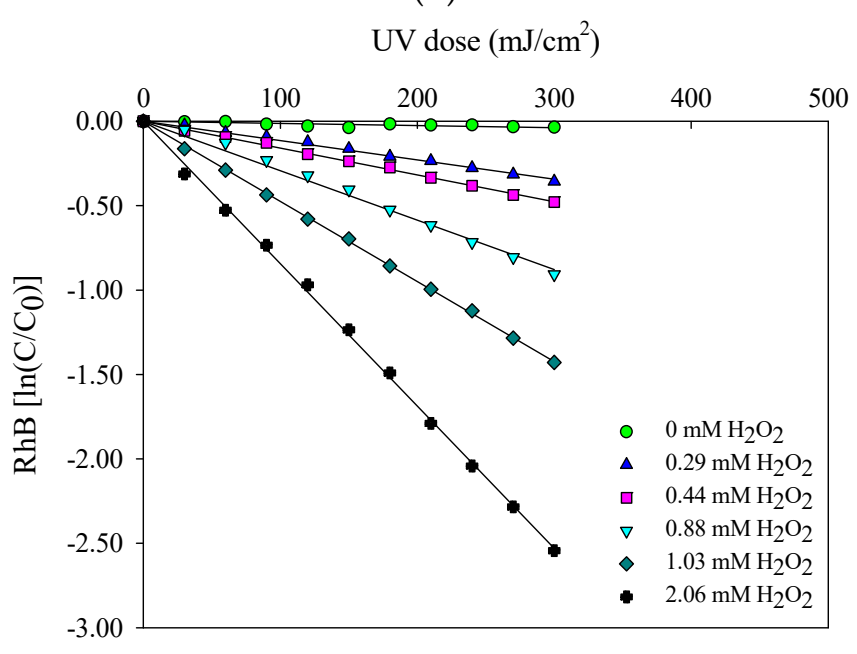

(d)

Figure 3. Color decay rate of RhB at different hydrogen peroxide concentrations by UV fluence $\left([\mathrm{RhB}]_{0}=1 \mu \mathrm{M}\right)$ of samples from plants: (a) C; (b) N; (c) Y; (d) B water treatment.

In plant $\mathrm{B}$, when $\mathrm{H}_{2} \mathrm{O}_{2}$ was injected at $0.29 \mathrm{mM}, 0.44 \mathrm{mM}, 0.88 \mathrm{mM}, 1.03 \mathrm{mM}$, and $2.06 \mathrm{mM}$, the variations in the RhB color decay rate at the UV dose of $300 \mathrm{~mJ} / \mathrm{cm}^{2}$ were observed not to affect the slope of the curve.

The data continuously measured by the portable $\mathrm{OH}$ radical scavenging demand analyzer are shown as a graph in Figure 4 . The RhB decay rate increased with increasing $\mathrm{H}_{2} \mathrm{O}_{2}$ concentration because additional $\mathrm{OH}$ radicals were generated in the reaction by UV. $\mathrm{RhB}$ cannot be decomposed by $\mathrm{UV}$ alone. The reaction rate of $\mathrm{OH}$ radicals and $\mathrm{RhB}$ was $2.5 \times 10^{5} \mathrm{M}^{-1} \mathrm{~s}^{-1}$. The results suggest that RhB is a suitable probe compound for measuring the $\mathrm{OH}$ radical scavenging demand, which is consistent with previous studies [16]. In this study, the continuous measurement of $\mathrm{RhB}$ decay allowed the calculation of $\mathrm{OH}$ radical scavenging demand. 


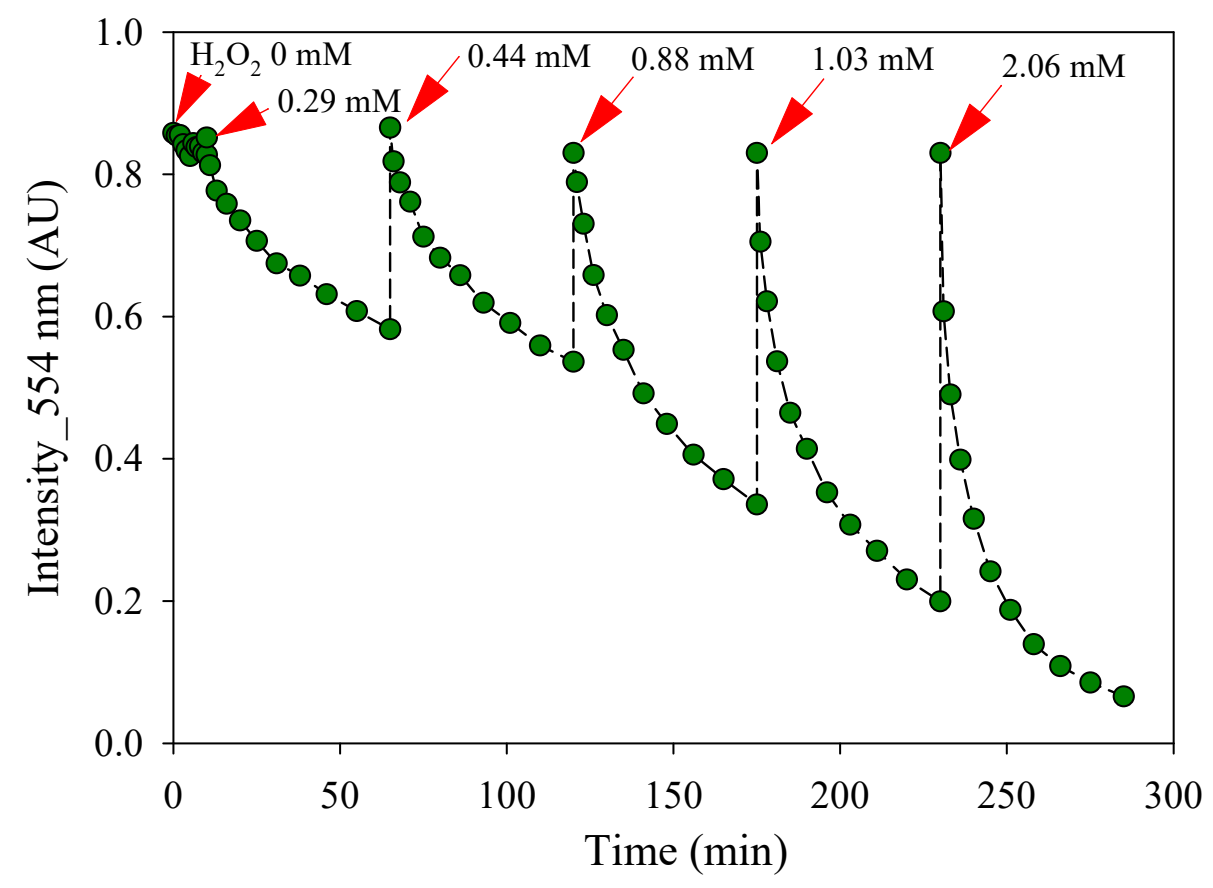

Figure 4. $\mathrm{RhB}$ color decay by adding $\mathrm{H}_{2} \mathrm{O}_{2}$ using the portable $\mathrm{OH}$ radical scavenging demand analyzer.

\subsection{Monitoring of $\mathrm{OH}$ Radical Scavenging Demand}

The result of calculating the $\mathrm{OH}$ radical scavenging demand for four samples using the portable $\mathrm{OH}$ radical scavenging demand analyzer using Equation (1) is shown in Figure 5 and Table 2. The $\mathrm{m}$ and $\mathrm{b}$ values for the $\mathrm{X}$ and $\mathrm{Y}$ axes obtained for each sample and the $\mathrm{OH}$ radical scavenging demand calculated using Equation (1) were $42,346 \mathrm{~s}^{-1}, 20,659 \mathrm{~s}^{-1}$, $32.232 \mathrm{~s}^{-1}$, and $81,669 \mathrm{~s}^{-1}$ for plants $\mathrm{C}, \mathrm{N}, \mathrm{Y}$, and B, respectively. These are the mean values of five measurements from different samples.

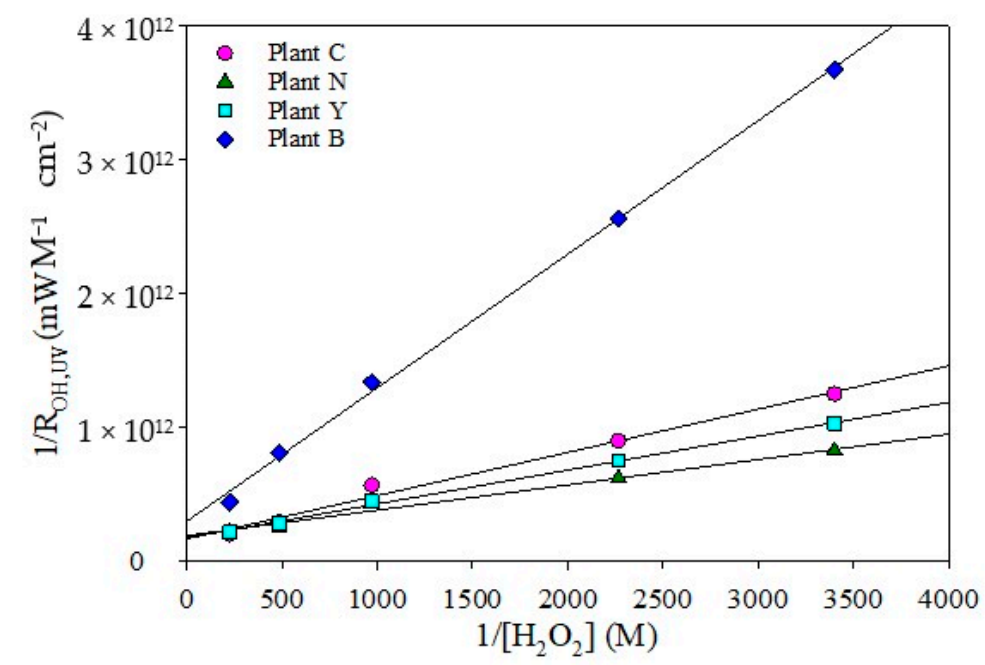

Figure 5. The $1 / \mathrm{R}_{\mathrm{OH}, \mathrm{UV}}$ values for four plants at different hydrogen peroxide concentrations $(0,0.29$, $0.44,0.88,1.03,2.06 \mathrm{mM})$ and $\left([\mathrm{RhB}]_{0}=1 \mu \mathrm{M}\right)$.

The results from the monitoring of $\mathrm{OH}$ radical scavenging demand for filtrates from plants $\mathrm{N}$ and $\mathrm{C}$ using the advanced low-pressure collimated beam for real-time $\mathrm{RhB}$ decay developed in this study are shown in Figure 6. The monitoring period for the $\mathrm{OH}$ radical scavenging demand was approximately one year. 
Table 2. OH radical scavenging demand measured using the portable analyzer.

\begin{tabular}{cc}
\hline Plants & Scavenging Demand (s $^{-\mathbf{1})}$ \\
\hline Plant C & $42,346 \pm 12,422$ \\
\hline Plant N & $20,659 \pm 4907$ \\
\hline Plant Y & $32,183 \pm 7327$ \\
\hline Plant B & $81,669 \pm 12,668$ \\
\hline
\end{tabular}

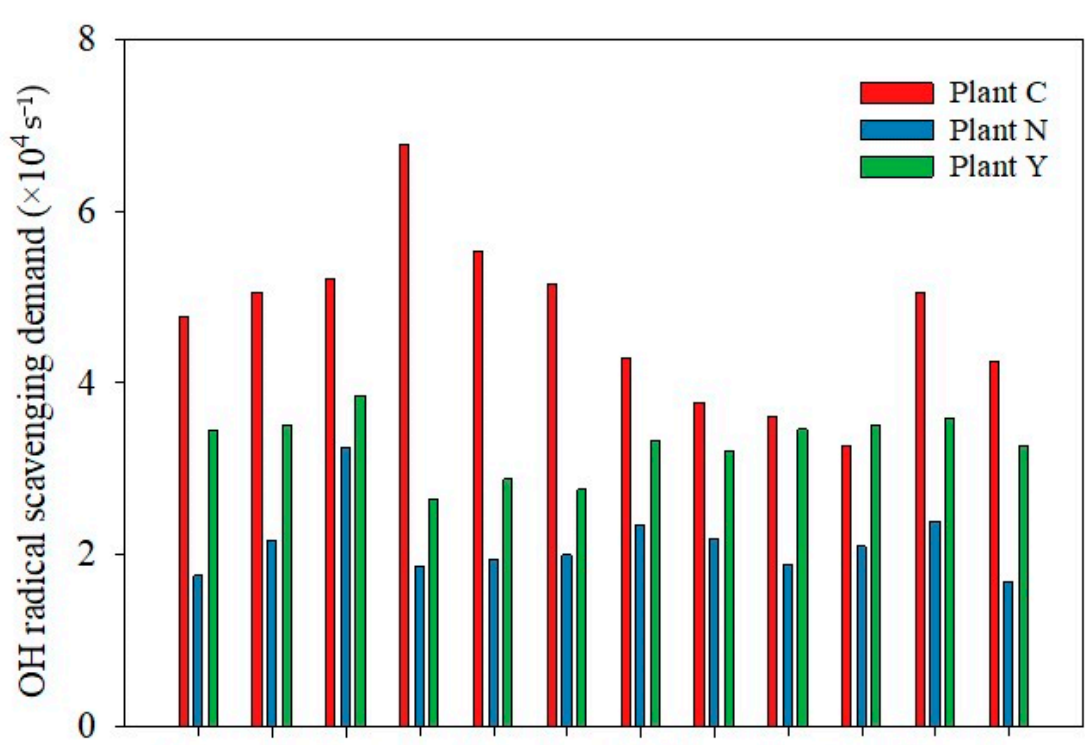

Jan. Feb. Mar. Apr. May June July Aug. Sep. Oct. Nov. Dec.

(a)

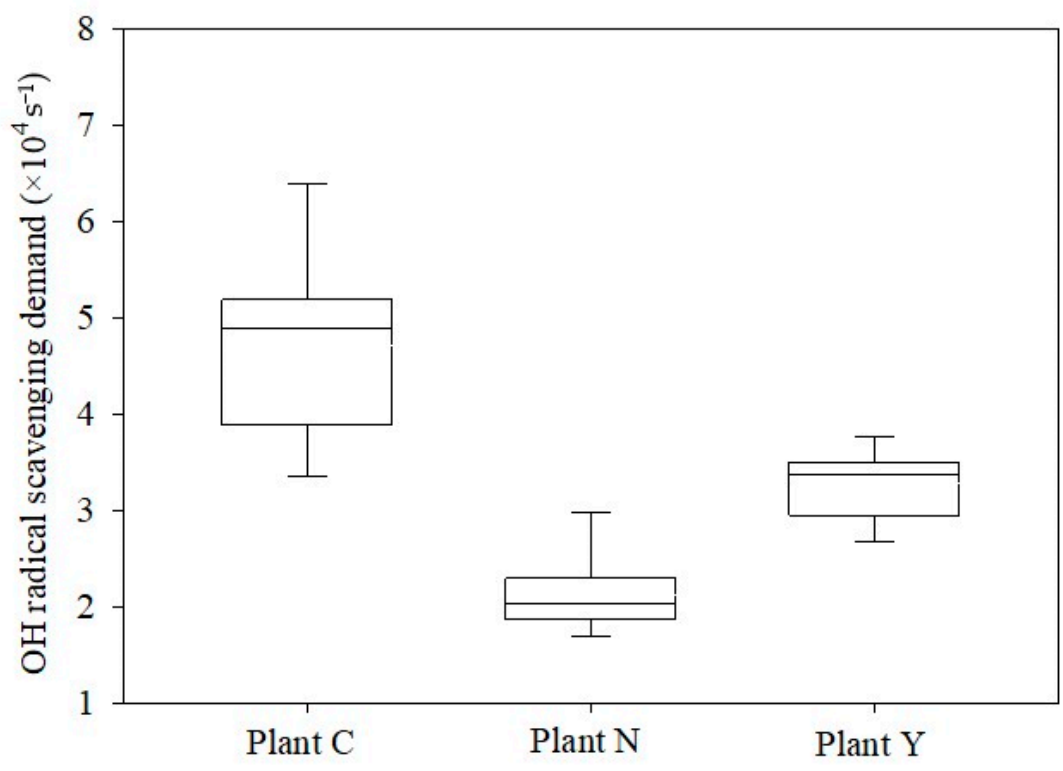

(b)

Figure 6. Variation of $\mathrm{OH}$ radical scavenging demand of plants $\mathrm{C}, \mathrm{N}$, and $\mathrm{Y}$ : (a) monthly variation; (b) box plot.

The mean $\mathrm{OH}$ radical scavenging demand measured using the portable analyzer was $20,659 \mathrm{~s}^{-1}$ with a range of $16,765 \mathrm{~s}^{-1}$ to $32,397 \mathrm{~s}^{-1}$ for plant $\mathrm{N} ; 42,346 \mathrm{~s}^{-1}$ with a range of $32,548 \mathrm{~s}^{-1}$ to $67,638 \mathrm{~s}^{-1}$ for plant $\mathrm{C}$; and $32,232 \mathrm{~s}^{-1}$ with a range of $27,324 \mathrm{~s}^{-1}$ to $38,424 \mathrm{~s}^{-1}$ for plant $\mathrm{Y}$. The measurement data showed that the $\mathrm{OH}$ radical scavenging 
demand fluctuated during the monitoring period. As shown in Figure 6a, the $\mathrm{OH}$ radical scavenging demand began to increase in early January to March in most cases, with the highest observed in March and April. The demand for plant $C$ decreased gradually after that, increased again in November, and decreased again in December. No significant variations were seen for plants $\mathrm{N}$ and $\mathrm{Y}$, although these tended to show a slight increase in November and decrease in December.

As shown in Figure 6b, the difference in $\mathrm{OH}$ radical scavenging demand values for plants $\mathrm{N}$ and $\mathrm{Y}$ was more than 1.55 times the average. Plant $\mathrm{C}$ showed higher values and significant variations in the $\mathrm{OH}$ radical scavenging demand. The average $\mathrm{OH}$ radical scavenging demand between $\mathrm{C}$ and $\mathrm{N}$ water plants showed a difference of more than 2.05 times. The difference in $\mathrm{OH}$ radical scavenging demand values for plants $\mathrm{C}$ and $\mathrm{N}$ was more than twice the average as well. This difference appeared to have resulted from the effects of water quality change including organic matter or algae concentrations in the influent raw water [21-24]. Therefore, plant $C$ showed significant variations regardless of the season, and the measurement of the $\mathrm{OH}$ radical scavenging demand is necessary for optimal process operation.

\section{Discussion}

The types and concentrations of inorganic species such as DOM, carbonates, bicarbonates, nitrites, and bromide ions are critical water quality parameters that influence the design and operation of the UV/hydrogen peroxide process. DOM can be analyzed easily using a device for continuous DOC measurement or UV254 absorbance, but $\mathrm{OH}$ radical scavenging demand cannot be measured continuously on site. The methods to measure $\mathrm{OH}$ radical scavenging demand are divided into those that measure individual water quality parameters or use alternative indicators for the water samples that contain various components. Methods that measure various water quality parameters at individual sites are time-consuming. To address this issue, a method of measuring the $\mathrm{OH}$ radical scavenging demand by measuring the $\mathrm{R}_{\mathrm{OH}, \mathrm{UV}}$ using pCBA has been proposed. This is an effective method with the advantage of using an analytical model with a smaller error than the method of measuring and analyzing individual water quality parameters. However, the method using pCBA as an indicator must be conducted in a laboratory given that an HPLC analysis system is needed. This study proposed an on-site continuous measurement method using a separate RT UV-Vis spectrometer with an RhB indicator and developed a portable $\mathrm{OH}$ radical scavenging demand analyzer. This analyzer can be carried to a site and used to measure $\mathrm{OH}$ radical scavenging demand easily and quickly. The results from monitoring water samples on-site using this analyzer suggest that the $\mathrm{OH}$ radical scavenging demand should be measured in the field and used to determine process operating parameters because there are wide deviations in the former depending on the season and site. The proposed portable $\mathrm{OH}$ radical scavenging demand analyzer can perform on-site measurements quickly and easily within an hour. The measured $\mathrm{OH}$ radical scavenging demand can be used as the input parameter for a process optimization reaction model to determine UV dose and hydrogen peroxide concentration required to achieve a target removal rate of the target compound.

\section{Conclusions}

This study proposed an on-site measurement method for measuring $\mathrm{OH}$ radical scavenging demand, an important parameter in the determination of the UV dose and hydrogen peroxide concentration for the UV/hydrogen peroxide process. As a result of applying the proposed method in the field, the following conclusions were obtained:

- A portable system of continuously measuring the RhB indicator via a real-time UV-Vis spectrometer enabled the on-site evaluation of the $\mathrm{OH}$ radical scavenging demand.

- The spectrometric method using the visible light region of the RhB indicator is simple and quick and does not require a separate HPLC, unlike the method using the pCBA indicator. 
- The mean OH radical scavenging demand for plants C, N, Y, and B were 42,346 s ${ }^{-1}$, $20,659 \mathrm{~s}^{-1}, 32,232 \mathrm{~s}^{-1}$, and $81,669 \mathrm{~s}^{-1}$, respectively. The $\mathrm{OH}$ radical scavenging demand tended to increase with DOC.

- Plant $\mathrm{C}$ showed the most significant variations in $\mathrm{OH}$ radical scavenging demand, probably because it was affected by other water quality indicators, such as algae influx that did not affect plants $\mathrm{N}$ and $\mathrm{Y}$.

Author Contributions: Conceptualization, T.-M.H.; methodology, S.-H.N. and T.-M.H.; software, S.-H.N.; investigation, S.-H.N. and J.-W.L.; validation, T.-M.H. and J.-W.K.; formal analysis, S.-H.N.; resources, T.-M.H.; data curation, T.-M.H. and E.-J.K.; writing—original draft preparation S.-H.N.; writing-review and editing, T.-M.H.; visualization, S.-H.N.; supervision, T.-M.H.; project administration, T.-M.H.; funding acquisition, T.-M.H. All authors have read and agreed to the published version of the manuscript.

Funding: This work was supported by the Korea Environment Industry \& Technology Institute (KEITI) through environmental R\&D project for developing innovative drinking water and wastewater technologies program, funded by the Korea Ministry of Environment (MOE) (grant number 2020002690003 and 2020002700004 ).

Institutional Review Board Statement: Not applicable.

Informed Consent Statement: Not applicable.

Data Availability Statement: Not applicable.

Conflicts of Interest: The authors declare no conflict of interest.

\section{References}

1. Huber, M.M.; Canonica, S.; Park, G.-Y.; von Gunten, U. Oxidation of Pharmaceuticals during Ozonation and Advanced Oxidation Processes. Environ. Sci. Technol. 2003, 37, 1016-1024. [CrossRef]

2. He, X.; Pelaez, M.; Westrick, J.A.; O'Shea, K.E.; Hiskia, A.; Triantis, T.; Kaloudis, T.; Stefan, M.I.; de la Cruz, A.A.; Dionysiou, D.D. Efficient removal of microcystin-LR by UV-C/H2O2 in synthetic and natural water samples. Water Res. 2012, 46, 1501-1510. [CrossRef] [PubMed]

3. Qu, S.; Kolodziej, E.P.; Cwiertny, D.M. Phototransformation Rates and Mechanisms for Synthetic Hormone Growth Promoters Used in Animal Agriculture. Environ. Sci. Technol. 2012, 46, 13202-13211. [CrossRef] [PubMed]

4. Glaze, W.H.; Kang, J.-W.; Chapin, D.H. The Chemistry of Water Treatment Processes Involving Ozone, Hydrogen Peroxide and Ultraviolet Radiation. Ozone: Sci. Eng. 1987, 9, 335-352. [CrossRef]

5. von Gunten, U. Ozonation of drinking water: Part I. Oxidation kinetics and product formation. Water Res. 2003, 37, 1443-1467. [CrossRef]

6. Wols, B.; Hofman-Caris, C. Review of photochemical reaction constants of organic micropollutants required for UV advanced oxidation processes in water. Water Res. 2012, 46, 2815-2827. [CrossRef] [PubMed]

7. Grebel, J.E.; Pignatello, J.J.; Mitch, W.A. Effect of Halide Ions and Carbonates on Organic Contaminant Degradation by Hydroxyl Radical-Based Advanced Oxidation Processes in Saline Waters. Environ. Sci. Technol. 2010, 44, 6822-6828. [CrossRef]

8. Liao, C.-H.; Kang, S.-F.; Wu, F.-A. Hydroxyl radical scavenging role of chloride and bicarbonate ions in the $\mathrm{H}_{2} \mathrm{O}_{2} / \mathrm{UV}$ process. Chemosphere 2001, 44, 1193-1200. [CrossRef]

9. Kwon, M.; Kim, S.; Yoon, Y.; Jung, Y.; Hwang, T.-M.; Lee, J.; Kang, J.-W. Comparative evaluation of ibuprofen removal by $\mathrm{UV} / \mathrm{H}_{2} \mathrm{O}_{2}$ and UV/S2O82 - processes for wastewater treatment. Chem. Eng. J. 2015, 269, 379-390. [CrossRef]

10. Donham, J.E.; Rosenfeldt, E.J.; Wigginton, K.R. Photometric hydroxyl radical scavenging analysis of standard natural organic matter isolates. Environ. Sci. Process. Impacts 2014, 16, 764-769. [CrossRef]

11. Rosenfeldt, E.J.; Linden, K.G. The $\mathrm{R}_{\mathrm{OH}, \mathrm{UV}}$ concept to characterize and the model $\mathrm{UV} / \mathrm{H}_{2} \mathrm{O}_{2}$ process in natural waters. Environ. Sci. Technol. 2007, 41, 2548-2553. [CrossRef]

12. Elovitz, M.S.; Von Gunten, U. Hydroxyl Radical/Ozone Ratios During Ozonation Processes. I. The Ret Concept. Ozone: Sci. Eng. 1999, 21, 239-260. [CrossRef]

13. Stefan, M.I. Advanced Oxidation Processes for Water Treatment: Fundamentals and Applications; IWA Publishing: London, UK, 2017; ISBN 978-178-040-718-0.

14. Satoh, A.Y.; Trosko, J.E.; Masten, S.J. Methylene Blue Dye Test for Rapid Qualitative Detection of Hydroxyl Radicals Formed in a Fenton's Reaction Aqueous Solution. Environ. Sci. Technol. 2007, 41, 2881-2887. [CrossRef]

15. Wang, C.; Rosenfeldt, E.; Li, Y.; Hofmann, R. External Standard Calibration Method To Measure the Hydroxyl Radical Scavenging Capacity of Water Samples. Environ. Sci. Technol. 2020, 54, 1929-1937. [CrossRef] [PubMed]

16. Kwon, M.; Kim, S.; Yoon, Y.; Jung, Y.; Hwang, T.-M.; Kang, J.-W. Prediction of the removal efficiency of pharmaceuticals by a rapid spectrophotometric method using Rhodamine $\mathrm{B}$ in the $\mathrm{UV} / \mathrm{H}_{2} \mathrm{O}_{2}$ process. Chem. Eng. J. 2014, 236, 438-447. [CrossRef] 
17. Hwang, T.-M.; Nam, S.-H.; Lee, J.; Koo, J.-W.; Kim, E.; Kwon, M. Hydroxyl radical scavenging factor measurement using a fluorescence excitation-emission matrix and parallel factor analysis in ultraviolet advanced oxidation processes. Chemosphere 2020, 259, 127396. [CrossRef]

18. Han, S.-K.; Nam, S.-N.; Kang, J.-W. OH radical monitoring technologies for AOP advanced oxidation process. Water Sci. Technol. 2002, 46, 7-12. [CrossRef]

19. Ding, X.; Gutierrez, L.; Croue, J.-P.; Li, M.; Wang, L.; Wang, Y. Hydroxyl and sulfate radical-based oxidation of RhB dye in $\mathrm{UV} / \mathrm{H}_{2} \mathrm{O}_{2}$ and $\mathrm{UV} /$ persulfate systems: Kinetics, mechanisms, and comparison. Chemosphere 2020, 253, 126655. [CrossRef]

20. Keen, O.S.; McKay, G.; Mezyk, S.P.; Linden, K.G.; Rosario-Ortiz, F.L. Identifying the factors that influence the reactivity of effluent organic matter with hydroxyl radicals. Water Res. 2014, 50, 408-419. [CrossRef]

21. Takaara, T.; Sano, D.; Masago, Y.; Omura, T. Surface-retained organic matter of Microcystis aeruginosa inhibiting coagulation with polyaluminum chloride in drinking water treatment. Water Res. 2010, 44, 3781-3786. [CrossRef]

22. Kwon, M.; Kim, S.; Jung, Y.; Hwang, T.-M.; Stefan, M.I.; Kang, J.-W. The Impact of Natural Variation of OH Radical Demand of Drinking Water Sources on the Optimum Operation of the UV/ $\mathrm{H}_{2} \mathrm{O}_{2}$ Process. Environ. Sci. Technol. 2019, 53, 3177-3186. [CrossRef] [PubMed]

23. Li, L.; Gao, N.; Deng, Y.; Yao, J.; Zhang, K. Characterization of intracellular \& extracellular algae organic matters (AOM) of Microcystic aeruginosa and formation of AOM-associated disinfection byproducts and odor \& taste compounds. Water Res. 2012, 46, 1233-1240. [CrossRef] [PubMed]

24. Lee, J.; Nam, S.-H.; Koo, J.-W.; Kim, E.; Hwang, T.-M. Comparative evaluation of 2-Isopropyl-3-methoxypyrazine, 2-Isobutyl-3methoxypyrazine, and 2,4,6-Trichloroanisole degradation by ultraviolet/chlorine and ultraviolet/hydrogen peroxide processes. Chemosphere 2021, 279, 130513. [CrossRef] [PubMed] 